\title{
White muscle disease in three selenium deficient beef and dairy calves in Argentina and Uruguay
}

\author{
Alejandro Martín Rodriguez ${ }^{*} \odot$ Carlos Omar Schild ${ }^{2}$ Germán José Cantón ${ }^{3}$ \\ Franklin Riet-Correa ${ }^{2}$ Joaquín Ignacio Armendano ${ }^{4}$ Rubén Darío Caffarena $^{2}$ Emilio César Brambilla ${ }^{3}$ \\ Juan Agustín García ${ }^{5}$ Eleonora Lidia Morrell ${ }^{3}$ Robert Poppenga $^{6}$ Federico Giannitti $^{7,2}$
}

\author{
Instituto Nacional de Tecnología Agropecuaria (INTA), Cuenca del Salado, Rauch, 7203, Buenos Aires, Argentina. E-mail: rodriguez.alejandro@inta.gob.ar. \\ *Corresponding author. \\ ${ }^{2}$ Instituto Nacional de Investigación Agropecuaria (INIA), La Estanzuela, Colonia, Uruguay. \\ ${ }^{3}$ Instituto Nacional de Tecnología Agropecuaria (INTA), Balcarce, Buenos Aires, Argentina. \\ ${ }^{4}$ Facultad de Ciencias Agrarias, Universidad Nacional de Mar del Plata, Balcarce, Buenos Aires, Argentina. \\ ${ }^{5}$ Centro Universitario Regional Este, Universidad de la República, Treinta y Tres, Uruguay. \\ ${ }^{6}$ California Animal Health and Food Safety (CAHFS), Laboratory, School of Veterinary Medicine, University of California, Davis, CA, USA. \\ ${ }^{7}$ Veterinary Population Medicine Department, University of Minnesota, Saint Paul, MN, USA.
}

\begin{abstract}
White muscle disease (WMD), nutritional myodegeneration or enzootic muscular dystrophy, is a nutritional condition associated with selenium and/or vitamin E deficiency in ruminants. These elements are constituents of the major body antioxidant systems. Depletion of selenium results in oxidative damage to cardiac and skeletal muscle cells, resulting in myodegeneration and myonecrosis, typical lesions of WMD. Selenium deficiency is common in South America, but WMD is underreported. This research describes clinical, biochemical and pathological findings in two episodes of WMD associated with selenium deficiency in beef and dairy calves in Argentina and Uruguay with concurrent copper deficiency in one of them, which resulted in spontaneous calf mortality. Further studies are necessary to estimate the true incidence and economic impact of clinical and subclinical mineral deficiencies in livestock production systems in the southern cone of South America.

Key words: calf mortality, cardiac failure, mineral deficiencies, nutritional myopathy, South America.
\end{abstract}

Doença do músculo branco em três bezerros para carne e leite deficientes em selênio na Argentina e Uruguai

RESUMO: Doença do músculo branco (DMB), miodegeneração nutricional ou distrofia muscular enzoótica é uma condição nutricional associada à deficiência de selênio elou vitamina E em ruminantes. Esses elementos são constituintes dos principais sistemas antioxidantes do corpo. O esgotamento de selênio resulta em dano oxidativo às células musculares cardiacas e esqueléticas, resultando em miodegeneração e mionecrose, lesões típicas da DMB. A deficiência de selênio é comum na América do Sul, mas a DMB está subnotificada. Este trabalho descreve os achados clínicos, bioquímicos e patológicos em dois surtos de DMB associados à deficiência de selênio em bezerros para carne e leite na Argentina e Uruguai com concomitante deficiência de cobre em um surto, que resultaram em mortalidade espontânea de bezerros. São necessários mais estudos para estimar a verdadeira incidência e impacto econômico das deficiências minerais clínicas e subclínicas nos sistemas de produção pecuária no sul da América do Sul.

Palavras-chave: mortalidade de bezerros, insuficiência cardiaca, deficiências minerais, miopatia nutricional, América do Sul.

\section{INTRODUCTION}

Selenium (Se), and vitamin E have important antioxidant functions that are crucial in protecting the integrity of the cell membranes against oxidative stress (KUTIL et al., 2010). Selenium deficiency is common in ruminants, mainly due to insufficient dietary levels or the formation of insoluble compounds in the rumen that inhibit their absorption (SPEARS, 2003). Vitamin E deficiency in ruminants is usually associated with prolonged ingestion of low quality forage (CORT et al., 1983).

"White muscle disease" (WMD), also referred as nutritional myodegeneration or enzootic muscular dystrophy, is a pathological entity caused by Se (ANDERSON et al., 1977) and/or vitamin E deficiency (MAAS et al., 1984). Lesions in WMD are mediated by oxidative damage to cell membranes, which allows extracellular calcium to flow into the damaged cells, causing activation of calcium-dependent 
proteases that then degrade myofibrils and other cellular components, leading to myodegeneration and myonecrosis (COOPER \& VALENTINE, 2016). Additionally, WMD is considered a multifactorial condition; exercise, overfeeding, excessive dietary intake of polyunsaturated fatty acids, and stress can be contributing factors (PAVLATA et al., 2001). Furthermore, it has been suggested that $\mathrm{Cu}$ deficiency may be potentially involved in the pathogenesis of the WMD, since this element is a cofactor of antioxidant enzymes (ATAOLLAHI et al., 2013).

Livestock production systems in Argentina and Uruguay are mainly based on natural grasslands and cultivated pastures. Selenium and $\mathrm{Cu}$ deficiencies have been described in cattle from this region; however, clinic pathological descriptions of spontaneous WMD are scarce (PODESTÁ et al., 1976; DUFFY et al., 1986) and probably underreported, given the relatively low proportion of disease outbreaks and livestock mortality events that are subjected to laboratory diagnostic investigation in the region (SPÄTH et al. 2012). This research described two episodes of WMD associated with Se deficiency in beef and dairy calves from Argentina and Uruguay, with concomitant copper deficiency in one of them.

\section{MATERIALS AND METHODS}

Episode 1 occurred in August 2013 in a beef cow-calf herd located in Pila department, Buenos Aires, Argentina. Five of 30 (16.7\%), 4- to 20-day-old calves showed weakness, prostration, inability to stand, respiratory distress and death within 48 hours. Episode 2 occurred in a dairy farm located in the department of Florida, Uruguay, in November 2015. One of 29 (3.4\%), 60-day-old Holstein calves fed with milk replacer, pasture, hay and commercial ration, died suddenly in a collective rearing pen.

Two calves from episode 1 (A-B) and one calf (C) from episode 2 were necropsied and tissue samples were immersion-fixed in $10 \%$ neutral buffered formalin, embedded in paraffin, sectioned at $4-5 \mu \mathrm{m}$ and stained with hematoxylin and eosin (HE) for microscopic examination. Selenium concentration was assessed in formalin-fixed liver from calves A-C by a hydride vapor generation inductively coupled plasma spectrometer (Thermo ICAP 6500, Thermo Scientific, Waltham, MA). Copper quantification was performed by atomic absorption spectrophotometry in fresh/ frozen liver samples from calves A-B, and serum from two asymptomatic calves (D-E) from episode 1 (PIPER \& HIGGINS, 1967). Additionally, plasma glutathione peroxidase (GPx) activity was measured by a kinetic method (PAGLIA \& VALENTINE, 1967) using commercial reagents (Randox Glutathione PeroxidaseRansel, Crumlin, Ireland) in 19 asymptomatic calves from episode 1 .

\section{RESULTS AND DISCUSSION}

Pathologic examination of calf A (episode 1) revealed pallor of the skeletal muscles of the thigh, cardiac dilation, ascites and hydrothorax. In calf B (episode 1), there was dilation of the right cardiac ventricle, with whitish striations and poorly-demarcated areas in the myocardium of the left ventricular wall and posterior papillary muscle. There was mild/moderate hydrothorax, hydroperitoneum and hydropericardium. In addition, there was moderate hepatomegaly and the liver had a diffuse, slightly accentuated lobular pattern. Multifocal myocardial degeneration and severe necrosis of myofibrils with sarcoplasmic mineralization was found histologically in both calves, with accompanying histiocytic inflammatory infiltrate in the myocardium of calf A. In the superficial gluteal muscle of calf $\mathrm{B}$, there was multifocal myofibrillar degeneration and inflammation. In the liver of calves A and $\mathrm{B}$, there was severe centrilobular congestion with hepatocellular degeneration and necrosis. In the lungs of calves A and B, there was intra-alveolar edema and alveolar macrophages with intracytoplasmic hemosiderin granules ("heart failure cells").

At necropsy of calf $\mathrm{C}$ (episode 2), the heart had a rounded contour due to bilateral ventricular dilation (Figure 1A), approximately $30 \%$ of the ventricular myocardium had extensive areas of pallor (Figure 1B), and there was moderate hydropericardium. The liver had a diffuse undulating irregular capsular surface, and there was a pronounced accentuation of the lobular pattern of the hepatic parenchyma ("nutmeg" liver, Figure 1D).Lungs had severe diffuse bilateral edema and congestion with expansion of the interlobular septae (Figure 1E). Heart and skeletal muscles had polyphasic multifocal segmental degeneration and necrosis with sarcoplasmic mineralization (Figure 1C). There was myocardial fibrosis and histiocytic myocarditis. In the liver, there was centrilobular and mid-zonal hemorrhage with rare hepatocellular necrosis and atrophy of hepatic cords, and perivenular fibrosis. Pulmonary lesions were similar to those described in calves A and B, including infiltration of hemosiderin-laden macrophages in alveolar spaces (Figure 1F).

Hepatic Se and $\mathrm{Cu}$, and serum $\mathrm{Cu}$ concentrations are summarized in table 1. Furthermore, considering a cutoff value of 30U/gHb/min (MAAS \& VALBERG, 2015), 7/19 asymptomatic calves (F-X) from episode 1 had reduced GPx activity $(26.5 \pm 1.4 \mathrm{U} / \mathrm{gHb} / \mathrm{min})$ (Table 2$)$. 


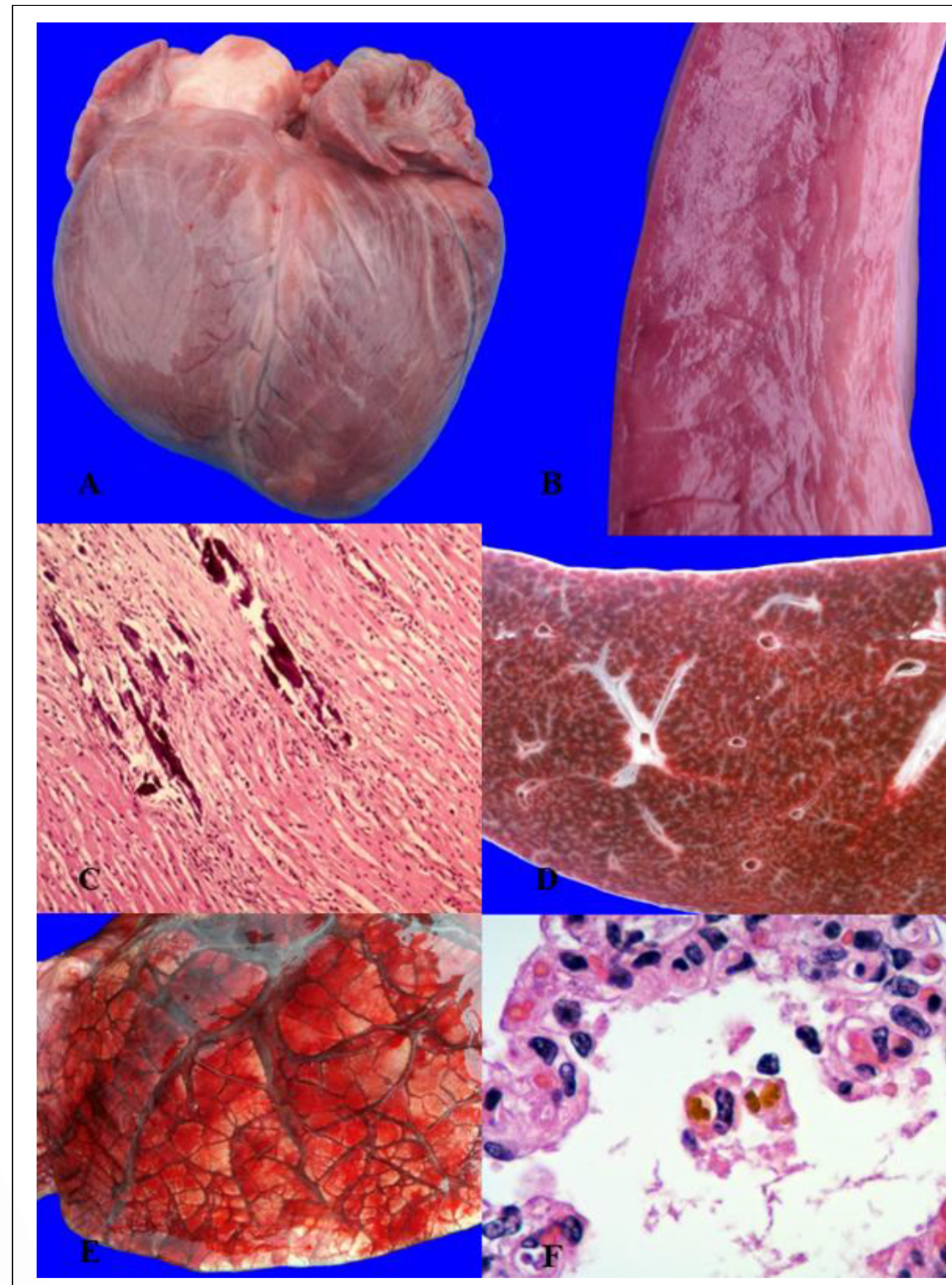

Figure 1 - A: calf C. The heart has a rounded shape due to dilation of the right ventricle. B: calf C. Heart, transmural section of the right ventricular free wall showing a diffuse, indiscrete band of pallor on the subendocardial myocardium (right side). C: Calf C. Heart, segmental sarcoplasmic mineralization of two myocardiocytes (center). HE stain. D: calf C. A cross section of the hepatic parenchyma shows a diffuse enhancement of the lobular pattern, typical of chronic hepatic congestion secondary to heart failure ("nutmeg liver"). E: Calf C. Severe diffuse pulmonary edema with marked expansion of the interlobular septae. F: calf C. Lung, alveolar macrophages contain intracytoplasmic hemosiderin granules, known as "heart failure cells" (center). HE stain. 
Table 1 - Hepatic Se and $\mathrm{Cu}$, and serum $\mathrm{Cu}$ concentrations in calves from two episodes of white muscle disease. Reference ranges: Hepatic Se (MAAS \& VALBERG 2015), hepatic and serum Cu (MAAS \& SMITH 2015).

\begin{tabular}{lcccr}
\hline Calf & Episode & Hepatic Se (ppm, dry weight) & Hepatic Cu (ppm, dry weight) & Serum Cu (ppm, wet weight) \\
\hline A & 1 & 0.63 & 2.5 & NA \\
B & 1 & 0.44 & 31.1 & 0.64 \\
C & 2 & 0.29 & NA & NA \\
D & 1 & NA & NA & 0.23 \\
E & 1 & NA & NA & 0.37 \\
Reference range & $0.9-1.75$ & $90-350$ & $0.7-1.2$ \\
\hline
\end{tabular}

NA: not available.

Clinical signs and pathological findings in the affected calves from both episodes were compatible with WMD, and this condition was confirmed by the deficient levels of hepatic Se in all 3 necropsied calves. Additionally, subclinical Se deficiency was suspected in asymptomatic calves from episode 1 based on the reduced levels of plasma GPx activity (MAAS \& VALBERG, 2015). Although, the contributing role of vitamin E deficiency to WMD is well documented, vitamin E status was not assessed in these cases. There was no history of exposure to cardiotoxic substances or plants for either herd.

Table 2 - Plasma activity of glutathione peroxidase in 19 asymptomatic calves from episode 1 . Reference value: MAAS \& VALBERG, 2015.

\begin{tabular}{lc}
\hline Calf & GPx activity $(\mathrm{U} / \mathrm{gHb} / \mathrm{min})$ \\
\hline F & 29 \\
G & 31 \\
H & 31 \\
I & 39 \\
J & 26 \\
K & 38 \\
L & 31 \\
M & 29 \\
N & 47 \\
O & 42 \\
P & 36 \\
Q & 32 \\
R & 32 \\
S & 30 \\
T & 24 \\
U & 29 \\
V & 22 \\
W & 32 \\
X & 33 \\
Reference value & 30 \\
\hline & \\
\hline
\end{tabular}

Age plays an important role in the presentation of WMD. Selenium and $\mathrm{Cu}$ tissue concentrations in newborn calves are dependent on placental and colostrum/ milk transfer (ABDELRAHMAN \& KINCAID, 1992; ENJALBERT et al., 1999). Congenital WMD has been described in calves born to dams fed low Se diets during gestation (ABUTARBUSH \& RADOSTITS, 2003). Additionally, fast-growing calves up to 4 months of age are often highly susceptible to WMD (MAAS \& VALBERG, 2015). Because calves in the beef herd were within the first 20 days of life, and neonates as young as 4 days old were affected, we speculated that some calves may have been born with deficient or critical levels of Se and $\mathrm{Cu}$ in this herd. This emphasized that diets provided to pregnant cows and young calves should be properly balanced to assure adequate micronutrient intake.

Clinical signs of WMD may vary depending on the type of musculature predominantly affected. When myocardial muscle is affected, the onset of clinical signs is often peracute, with sudden weakness, depression, dyspnea, prostration and death in $<24 \mathrm{~h}$. When the skeletal muscles are mainly involved, the clinical course is often subacute to chronic, and is characterized by weakness, tremors, muscular rigidity and prolonged decubitus. In the cases presented herein, clinical course was subacute in calves A-B, and peracute in case $\mathrm{C}$; although, gross and microscopic lesions clearly indicated a chronic course in all cases.

At postmortem examination, multiple pale areas can be observed in skeletal muscles and/ or myocardium; cardiac lesions mainly affect the left ventricular wall and the interventricular septum (KENNEDY etal., 1987). Congestive heart failure occurs because of the myocardial lesions: cardiac ventricles may be dilated, hydropericardium, hydrothorax, ascites, pulmonary edema and/or chronic hepatic congestion are also described (MAAS \& VALBERG, 2015) and were present in all necropsied calves in 
this study. Microscopically, WMD is characterized by degeneration, necrosis and mineralization of cardiac and/or skeletal myocytes. Myofibrils showed multifocal areas of degeneration and necrosis, with or without mineralization, with non-suppurative inflammation mainly by macrophages, as well as fibrosis as a repair response in chronic cases (COOPER \& VALENTINE, 2016). In these cases, the degenerative and necrotizing myocardial lesions accompanied by myocardial fibrosis were considered the primary reason for the chronic active pulmonary and hepatic lesions typical of chronic heart failure seen in all 3 calves in this report.

We concluded that WMD is associated with in-farm production losses due to calf mortality in beef and dairy cattle in Argentina and Uruguay. Additional investigation is needed to assess the magnitude of these losses and better understand the impact of clinical and subclinical micronutrient and mineral deficiencies on health and production in livestock in South America.

\section{ACKNOWLEDGEMENTS}

The authors thank Ana Curbelo and Raúl Romero (veterinary practitioners), Yisell Perdomo (INIA), Lilian Lischinsky, Mónica Drake, Eduardo Fernández and Ernesto Odriozola (INTA) for technical and critical assistance.

\section{FUNDING}

Part of this research was funded by grant PNSA1115054 from the Argentinian "Instituto Nacional de Tecnología Agropecuaria" and grant PL_015 N-15156 from the Uruguayan "Instituto Nacional de Investigación Agropecuaria".

\section{BIOETHICS AND BIOSSECURITY COMMITTEE APPROVAL}

All procedures performed in studies involving animals were in accordance with the ethical standards of the institution or practice at which the studies were conducted.

\section{DECLARATION OF CONFLICTING INTERESTS} conflict of interest.

The authors declare that they do not have any

\section{REFERENCES}

ABDELRAHMAN, M.M.; KINCAID, R.L. Effects of concurrent deficiencies of phosphorus and copper in growing lambs on the concentration of minerals in tissues. Small Ruminant Research, 9, 229-241. 1992. Available from: $<$ http://www.smallruminantresearch. com/article/0921-4488(92)90153-U/pdf>. Accessed: Feb. 15, 2016. doi: 10.1016/0921-4488(92)90153-U.

ABUTARBUSH, S.M.; RADOSTITS, O.M. Congenital nutritional muscular dystrophy in a beef calf. The Canadian Veterinary Journal
44, 738-739. 2003. Available from: < www.ncbi.nlm.nih.gov/pmc/ articles/PMC340271/pdf/20030900s00020p738.pdf>. Accessed: Aug. $10,2017$.

ANDERSON, P.H. et al. The sequence of myodegeneration in nutritional myopathy of the older calf. The British Veterinary Journal 133, 160-165. 1977. Available from: $<$ https://www.sciencedirect.com/ science/article/pii/S0007193517341374>. Accessed: Nov. 10, 2016. doi: 10.1016/S0007-1935(17)34137-4.

ATAOLLAHI, F. et al. Evaluation of copper concentration in subclinical cases of white muscle disease and its relationship with cardiac troponin I. PloS One 8, 1-5. 2013. Available from: <http:// journals.plos.org/plosone/article?id=10.1371/journal.pone.0056163>. Accessed: Oct. 20, 2016. doi: 10.1371/journal.pone.0056163.

COOPER, B.; VALENTINE, B.A. Muscle and tendon. In: G. Maxie (ed), Jubb, Kennedy and Palmer's pathology of domestic animals, Vol.1. Editorial Saunders Ltd. Elsevier. Philadelphia (EEUU). 6 ${ }^{\text {th }}$ Edition. pp 214-218. 2016.

DUFFY, S.J. et al. Enfermedad del músculo blanco en terneros de cría. Veterinaria Argentina 21, 16-22 (in Spanish). 1986.

ENJALBERT, F. et al. Effects of pre-or postpartum selenium supplementation on Se status in beef cows and their calves. Journal of Animal Science, 77, 223-229. 1999. Available from: $<$ https://academic. oup.com/jas/article/77/1/223/4625370>. Accessed: Oct. 20, 2016. doi: $10.2527 / 1999.771223 x$.

KENNEDY, S. et al. Experimental myopathy in vitamin E and seleniumdepleted calves with and without added dietary polyunsaturated fatty acids as a model for nutritional degenerative myopathy in ruminant cattle. Research in Veterinary Science, 43, 384-394. 1987. Available from: <http://europepmc.org/abstract/med/3444984>. Accessed: Nov. $10,2016$.

KUTIL, B. et al. Alterations in serum selenium levels and their relation to troponin I in acute myocardial infarction. Molecular and Cellular Biochemistry, 345, 23-27. 2010. Available from: $<$ https://link.springer.com/article/10.1007/s11010-010-0555-x >. Accessed: Nov. 10, 2016. doi: 10.1007/s11010-010-0555-x.

CORT, W.M. et al. Vitamin E content of feedstuffs determined by high-performance liquid chromatographic fluorescence. Journal of Agricultural and Food Chemistry 31, 1330-1333. 1983. Available from: $<$ https://pubs.acs.org/doi/pdf/10.1021/jf00120a045>. Accessed: Dec. 5, 2016.

MAAS, J. et al. Nutritional myodegeneration associated with vitamin E deficiency and normal selenium status in lambs. Journal of the American Veterinary Medical Association 184, 201-204. 1984. Available from: <http://europepmc.org/abstract/ med/6698855>. Accessed: Nov. 10, 2016.

MAAS, J.; SMITH, B.P. Copper deficiency in ruminants. In: B.P. Smith (ed), Large Animal Internal Medicine. $5^{\text {th }}$ Ed. Elsevier, St Louis, Missouri (USA), pp. 837-840. 2015.

MAAS, J.; VALBERG, S.J. Nutritional and toxic rhabdomyolysis. In: B.P. Smith (ed), Large Animal Internal Medicine. $5^{\text {th }}$ Ed. Elsevier, St Louis, Missouri (USA), pp. 1291-1294. 2015.

PAGLIA, D.E.; VALENTINE, W.N. Studies of the quantitative and qualitative characterization of erythrocyte glutathione peroxidase. Journal of Laboratory and Clinical Medicine, 70, 
158-169. 1967. Available from: <http://www.translationalres.com/ article/0022-2143(67)90076-5/abstract>. Accessed: Dec. 10, 2016.

PAVLATA, L. et al. Muscular dystrophy in dairy cows following a change in housing technology. Acta Veterinaria Brno 70, 269 275. 2001. Available from: <https://actavet.vfu.cz/media/pdf/ avb_2001070030269.pdf>. Accessed: Oct. 20, 2016.

PIPER, H.G.; HIGGINS, G. Estimation of trace metals in biological material by atomic spectrophotometry. Proceedings of the Association of Clinical Biochemists 7, 190-195. 1967. Available from: <http:// journals.sagepub.com/doi/pdf/10.1177/036985646700400701>. Accessed: Nov. 10, 2016. doi: 10.1177/036985646700400701.

PODESTÁ, M. et al. Distrofia muscular nutricional (DMN). Primera comprobación en bovinos del Uruguay. Veterinaria
(Uruguay) 63, 19-35 (in Spanish). 1976. Available from: <http:// www.sidalc.net/cgi-bin/wxis.exe/?IsisScript=FVL.xis\&meth $\mathrm{od}=$ post $\&$ formato $=2 \&$ cantidad $=1 \&$ expresion $=\mathrm{mfn}=003271>$. Accessed: Dec. 10, 2016.

SPÄTH, E. J. A. et al. Enfermedades de los bovinos diagnosticadas por veterinarios en el centro-sur de Buenos Aires. Años $2001 \mathrm{al}$ 2007. Ediciones del Instituto Nacional de Tecnología Agropecuaria (INTA), Boletín técnico 161, (in Spanish). 2012. Available from: $<$ https://inta.gob.ar/sites/default/files/script-tmp-inta_boletin161pip. pdf $>$. Accessed: Sept. 15, 2016.

SPEARS, J.W. Trace mineral bioavailability in ruminants. The Journal of Nutrition 13, 1506S-1509S. 2003. Available from: $<$ https://academic.oup.com/jn/article/133/5/1506S/4558538>. Accessed: Nov. 10, 2016. doi: 10.1093/jn/133.5.1506S. 